\title{
Evaluation of Antisnake Venom Activities of Some Medicinal Plants Using Albino Rats
}

Ibrahim Sani ${ }^{*}$, Fatima Bello, Isah Musa Fakai and Abubakar Abdulhamid

Department of Biochemistry, Faculty of Life Sciences, Kebbi State University of Science and Technology, Aliero, Nigeria

DOI: $10.36348 /$ sijtcm.2020.v03i06.001

| Received: 20.05.2020 | Accepted: 02.06.2020 | Published: 06.06.2020

*Corresponding author: Ibrahim Sani

\section{Abstract}

Snakebite is a neglected public health problem in most of the countries in Africa. Its means of treatment is parenteral administration of serum-based antivenins. But due to the limitations of these antivenins, snakebite victims mostly depend on herbal antidotes. Hence, this research was designed to screen the antisnake venom activity of some medicinal plants on mixed venoms of Naja nigricollis, Echis ocellatus and Bitis arietans using Albino rats' model. Information on the medicinal plants used for the treatment of snakebite envenomation in Zuru Local Government Area was obtained through ethnobotanical survey. Four (4) most cited plants; Parkia biglobosa stem-bark, Calotropis procera root, Sterculia setigera stem-bark and Bauhinia rufescens seed were selected and screened against the venom-induced lethal effect on albino rats. Albino rats of both sexes were randomly divided into six (6) groups of five (5) rats each and used for the antivenom screening of each plant methanol extract. Group 1 received distilled water. Groups 2, 3 and 4 received $0.8 \mathrm{mg} / \mathrm{kg}$ b. wt. of the venom mixture, but 3 and 4 were treated with 200 and $400 \mathrm{mg} / \mathrm{kg} \mathrm{b}$. wt. of an extract respectively. Group 5 received $400 \mathrm{mg} / \mathrm{kg}$ b. wt. of an extract only. Finally, group 6 received $0.8 \mathrm{mg} / \mathrm{kg}$ b. wt. of the venom mixture and treated with standard antivenin. The plants' extracts exhibited antivenom activities with varying degrees of efficacy. At $400 \mathrm{mg} / \mathrm{kg} \mathrm{b}$. wt. of extract, the recorded mean animal survival times were $18.52 \pm 1.50 \mathrm{~h}, 14.04 \pm 4.79 \mathrm{~h}, 18.66 \pm 4.32 \mathrm{~h}$ and $5.96 \pm 2.79 \mathrm{~h}$ for $C$. procera root, P. biglobosa stem-bark, B. rufescens seed and S. setigera stem-bark extracts respectively. Thus, $B$. rufescens methanol seed extract was the most potent antivenom agent. These findings suggest that, the selected plants have potent antivenom activity on the selected snake venoms and can serve as lead for the development of safe, readily available and affordable antivenoms that can substitute the use of serum-based antivenins.

Keywords: Medicinal Plants, Snakebite, Venom, Envenomation, Antivenom.

Copyright @ 2020: This is an open-access article distributed under the terms of the Creative Commons Attribution license which permits unrestricted use, distribution, and reproduction in any medium for non-commercial use (NonCommercial, or CC-BY-NC) provided the original author and source are credited.

\section{INTRODUCTION}

Snakebite envenomation remains a common health problem in almost all rural areas of the tropics. Unfortunately, in most rural areas, modern health facilities are either very poor or completely absent [1]. In places where such facilities exist, delicate medicines such as serum-based antivenins (that require refrigeration) are not available due to erratic power supply. Considering the urgency required in administering antivenom after snakebite (that is before venom toxins overwhelm the body), transporting victims to far away city hospitals, where antivenins might be found, is in many cases fruitless. Furthermore, the conventional antivenins are expensive and thus not affordable to most poor victims. Additionally, the antivenins can cause adverse reactions, such as anaphylactic shock, pyrogen reaction and serum sickness [2]. They do not provide enough protection against venom induced toxicities, such as, necrosis, haemorrhage, cytotoxicity, nephrotoxicity, etc. [3].

Although no known plant-based antivenom is available in Nigerian markets yet, it is a common phenomenon to see some people simultaneously playing with different kinds of poisonous snakes in public places and during festivities. These people claim to have effective cure and themselves are immune to snakebites. They serve as the first points of call when snakebites occur in their communities and there are many instances where their medication evidently cured what could have been a fatal envenomation and all this 'power' comes from plants. This observation gives hope that if these plants are properly investigated there is a high possibility of coming up with effective and wide-spectrum antivenom at least against the common poisonous snakes found in Northern parts of Nigeria. 


\section{MATERIALS AND METHODS Area of Study/Sampling}

The appropriate plants were identified from snake-charmers and hunters of the Lelna tribe, Zuru, Kebbi State, Nigeria. Zuru is the headquarters of Zuru Emirate as well as Zuru Local Government Area of Kebbi State, Nigeria. It has an area of $653 \mathrm{~km}^{2}$ and geographical coordinates are $11^{\circ} 25^{\prime} 49^{\prime \prime}$ North, $5^{\circ} 14^{\prime}$ 15 " East. The main language spoken by the Lelna tribe is C'lele [4]. Acquaintances and informants were used to gain access to the snake-charmers and hunters. Information on the method of preparation, administration, dosages, etc. was also obtained. Zuru is the home to the Lelna tribe who are well-known for their successful use of plants in almost all their medications including prevention and treatment of snakebites.

\section{Experimental Animals}

Adult Wister albino rats of both sexes aged 2-3 months and weighing between $200-250 \mathrm{~g}$ were used for the experiments. They were purchased from National Veterinary Research Institute, Vom, Nigeria and kept under standard laboratory conditions (22$24^{\circ} \mathrm{C} ; 12: 12 \mathrm{~h}$ dark/light cycle). The animals were allowed free access to both food (commercial rodents pellets) and water ad libitum [5], they were allowed to acclimatize for 2 weeks. Weight of each rat was taken before the commencement of each experiment. All animal experiments were conducted in accordance with the guidelines for the use and care of experimental animals [6].

\section{Standard Snake Venom Antiserum (Antivenin)}

The lyophilized polyvalent snake venom antiserum (Batch No.: 01AS83659, Man. Date: March, 2018, Exp. Date: February, 2021) was used as standard to compare with the efficacy of the various plants extracts. It was produced by a standard pharmaceutical company (VINS Bioproducts Limited, Andhra Pradesh, India).

\section{Collection of Snakes}

The snake species; Naja nigricollis (blacknecked spitting cobra), Echis ocellatus (carpet viper) and Bitis arietans (puff adder) were captured and housed in wooden cages with the help of snake charmers. After collection, they were duly identified by a Zoologist at the Department of Animal and Environmental Biology, Kebbi State University of Science and Technology, Aliero, Nigeria.

\section{Milking of Venom}

The venoms were collected between $5.00 \mathrm{pm}$ to $6.30 \mathrm{pm}$, in a low light condition at ambient temperature according to the method of Goswami et al., [7] by using a short-acting general anesthesia; halothane (Piramal Healthcare Limited, U.K.). The glands below the eyes of each snake were compressed to release the stored venom into a clean and sterilized container.

\section{Preparation of Venom}

After milking, the venoms were mixed and lyophilized using a freeze-dryer (Millrock Technology, USA) and kept in a refrigerator (HR135A, HaierThermocool, Lagos, Nigeria) in a light resistant and airtight container. The lyophilized venom mixture was reconstituted in $0.9 \%$ saline (regarded as the venom) and used for the study. Before use, it was kept at $4{ }^{\circ} \mathrm{C}$. The venom concentration was expressed in terms of dry weight $(\mathrm{mg} / \mathrm{ml})[8]$.

\section{Ethnobotanical Survey}

Ethnobotanical data were collected through personal interviews with eleven (11) snake-charmers for the names (in Hausa Language) of the medicinal plants, parts used, method of preparation, dose and the mode of administration. The data collected were used to select four (4) most cited plants; Parkia biglobosa stem-bark, Calotropis procera root, Sterculia setigera stem-bark and Bauhinia rufescens seed for the antivenom screening in this study.

\section{Collection of the Selected Medicinal Plants}

The parts of the selected plants were collected on Saturday, 07 ${ }^{\text {th }}$ September, 2019 from Zuru town, Kebbi State, Nigeria. They were authenticated at the herbarium of the Department of Plant Science and Biotechnology, Kebbi State University of Science and Technology, Aliero, Nigeria.

\section{Preparation of the Plants' Methanol Extracts}

The plant extracts were prepared according to the method of Dupont et al., [9]. The collected plants parts were washed with clean water and air-dried under shade, pulverized using pestle and mortar. Five hundred grammes $(500 \mathrm{~g})$ of each powdered plant material was weighed and soaked in $1.5 \mathrm{~L}$ of $95 \%$ methanol. The mixture was then kept at room temperature for $48 \mathrm{~h}$ and filtered twice; initially with a muslin cloth and later with a Whatman filter paper No.1. The filtrates were evaporated to dryness at $40^{\circ} \mathrm{C}$ using rotary evaporator. The residues were used for the antivenom activity screening.

\section{Screening of the Extracts for Antivenom Activity}

For each of the four (4) plant extracts, thirty (30) rats were randomly distributed into six (6) groups of five (5) rats each.

Group 1: received only distilled water and served as normal control.

Group 2: were injected intraperitoneally (i.p.) only with $0.8 \mathrm{mg} / \mathrm{kg} \mathrm{b}$. wt. of the venom and served as venom control.

Group 3 and 4: served as treatment groups, they were injected (i.p.) with $0.8 \mathrm{mg} / \mathrm{kg} \mathrm{b}$. wt. of the venom, after $30 \mathrm{~min}$ they were treated orally with a plant extract at doses of 200 and 400 $\mathrm{mg} / \mathrm{kg}$ b. wt. respectively. 
Group 5: received only a plant extract at a dose of 400 $\mathrm{mg} / \mathrm{kg} \mathrm{b}$. wt. orally and served as extract control.

Group 6: were injected (i.p.) with $0.8 \mathrm{mg} / \mathrm{kg}$ b. wt. of the venom, after $30 \mathrm{~min}$, they were treated intravenously (i.v.) with standard conventional serum antivenin at a dose of $1 \mathrm{ml} / 0.6 \mathrm{mg}$ venom and served as standard control.

All the groups received same volume of preparations. In all the groups, the duration of animal survival and number of rats that survived were recorded for $24 \mathrm{~h} \mathrm{[10].}$

\section{DATA ANALYSIS}

The data generated from the study are presented as mean \pm SEM and subjected to one way analysis of variance (ANOVA) and statistical difference between the means were separated using New Duncan's Multiple Range Test at $\mathrm{P}<0.05$ with the aid of a statistical package (IBM SPSS Statistics 20)

\section{RESULTS}

\section{Ethnobotanical Survey for the Antivenom Medicinal Plants}

Eleven (11) medicinal plants were surveyed. The medium of preparation of each was either in water or milk, and the mode of administration was oral. Four (4) plants' materials with highest number of citations namely; Parkia biglobosa stem-bark (9), Calotropis procera root (9), Sterculia setigera stem-bark (8) and Bauhinia rufescens seed (8) were selected. The medicinal plants used in Zuru Emirate for the treatment of snakebite envenomation are presented in Table 1.

\section{Antisnake Venom Activities of the Selected Medicinal Plants}

The venom mixture at the dose of $0.8 \mathrm{mg} / \mathrm{kg}$

b. wt. produced $100 \%$ mortality in the albino rats. The mean survival times (MSTs) of the animals administered with the snake venom without any treatment were less than $1 \mathrm{~h}$ (Tables 2-5).

Table 2 presents the Antisnake venom activity of $C$. procera root methanol extract. There was significant increase $(\mathrm{P}<0.05)$ in the MST with increase in the dose of the extract. It shows that, the doses 200 and $400 \mathrm{mg} / \mathrm{kg} \mathrm{b}$. wt. of the extract produced MSTs of $11.25 \pm 1.54$ and $18.52 \pm 1.50 \mathrm{~h}$ respectively. But none of these doses was able to protect the animals from death as $100 \%$ mortality was recorded for each dose (Table 2).

The antisnake venom activity of $P$. biglobosa stem-bark methanol extract is presented in Table 3. There was a significant $(\mathrm{P}<0.05)$ increase in the MST $(12.29 \pm 4.55 \mathrm{~h})$ upon administration of 200 $\mathrm{mg} / \mathrm{kg}$ b. wt. compared to the venom control group. But, there was no significant difference between the MSTs $(12.29 \pm 4.55$ and $14.04 \pm 4.79 \mathrm{~h})$ at 200 and $400 \mathrm{mg} / \mathrm{kg}$ b. wt. doses of the P. biglobosa stem-bark extract respectively. In all these doses administered, none protected the animals from death (Table 3 ).

The methanol extract of $B$. rufescens seed significantly increased mean survival time (MST) at the dose of $200 \mathrm{mg} / \mathrm{kg} \mathrm{b}$. wt., but could not protect the animals from death at that dose (Table 4). The dose of the plant extract when doubled to $400 \mathrm{mg} / \mathrm{kg}$ b. wt. was found to be more effective against the venom, presenting MST of $18.66 \pm 4.32 \mathrm{~h}$. At this dosage, the percentage of animal survival was significantly $(\mathrm{P}<0.05)$ increased to $20 \%$ compared to the animal group treated with the standard antivenin with $100 \%$ survival rate (Table 4).

The antisnake venom activity of $S$. setigera stem-bark methanol extract is presented in Table 5. In all the doses administered, none protected the animals from death. Thus, at $400 \mathrm{mg} / \mathrm{kg} \mathrm{b}$. wt. extract dose, a significant $(\mathrm{P}<0.05)$ increase in animal MST of $5.96 \pm 2.79 \mathrm{~h}$ was observed (Table 5). At 200 $\mathrm{mg} / \mathrm{kg} \mathrm{b}$. wt. of the extract, there was no significant $(\mathrm{P}>0.05)$ increase in the MST when compared to that of the venom control group.

Table 6 presents comparative analysis of the MSTs for selected plants. All the animals in the extract control group (group 6) for each plant presented $100 \%$ survival and with no sign of toxicity. At $200 \mathrm{mg} / \mathrm{kg} \mathrm{b}$. wt., the animals administered with $P$. biglobosa stem-bark extract presented the longest MST of $12.29 \pm 4.55$ h. C. procera and B. rufescens follow $P$. biglobosa in terms of the potency at this particular dose $(200 \mathrm{mg} / \mathrm{kg} \mathrm{b}$. wt.) with $11.25 \pm 1.54$ and $8.19 \pm 5.33 \mathrm{~h}$ respectively. The animals with least MST were those treated with $S$. setigera stembark extract with $3.98 \pm 0.54 \mathrm{~h}$ (Table 6). At 400 $\mathrm{mg} / \mathrm{kg} \mathrm{b}$. wt., of plant extract, animals treated with $B$. rufescens seed extract have the longest MST of 18.66 $\pm 4.32 \mathrm{~h}$ compared to those of the animals treated with the other plants. Eventually, animals treated with $400 \mathrm{mg} / \mathrm{kg} \mathrm{b}$. wt. of $S$. setigera have the least MST of $5.96 \pm 2.79 \mathrm{~h}$.

Hence, when compared with the activity of the standard antivenin, the percentage efficacy in terms of the antivenom activities of the test plants at $400 \mathrm{mg} / \mathrm{kg} \mathrm{b}$. wt. of the extract, is as follows (from the most active to the one with least activity): $B$. rufescens seed $(78 \%)>C$. procera root $(77 \%)>P$. biglobosa stem-bark $(59 \%)>S$. setigera stem-bark (25\%) respectively. Thus, B. rufescens seed extract was recorded as the most active at $400 \mathrm{mg} / \mathrm{kg}$ b. wt. 
Table-1: Medicinal Plants Used in Zuru for the Treatment of Snakebite Envenomation

\begin{tabular}{|c|c|c|c|c|c|c|}
\hline $\mathbf{S} / \mathbf{N}$ & $\begin{array}{c}\text { Plant Botanical } \\
\text { Name }\end{array}$ & $\begin{array}{l}\text { Name in } \\
\text { Hausa } \\
\text { Language }\end{array}$ & $\begin{array}{l}\text { Part of } \\
\text { the } \\
\text { Plant } \\
\text { Used }\end{array}$ & $\begin{array}{c}\text { Number of } \\
\text { Citations }\end{array}$ & Mode of Preparation & $\begin{array}{c}\text { Mode of } \\
\text { Administration }\end{array}$ \\
\hline 1 & Calotropis procera & Tumfafiya & Root & 9 & $\begin{array}{l}\text { Dried powdered } \\
\text { sample soaked in milk. }\end{array}$ & $\begin{array}{l}\text { A cup, three times a } \\
\text { day for three days. }\end{array}$ \\
\hline 2 & Balanite aegyptica & Aduwa & $\begin{array}{l}\text { Stem- } \\
\text { Bark }\end{array}$ & 3 & $\begin{array}{l}\text { The dried pulverized } \\
\text { bark is usually soaked } \\
\text { in water. }\end{array}$ & $\begin{array}{l}\text { Taken daily until } \\
\text { relieved. }\end{array}$ \\
\hline 3 & Azadirachta indica & $\begin{array}{l}\text { Dogon yaro / } \\
\text { Darbejiya }\end{array}$ & Leaf & 7 & $\begin{array}{l}\text { Fresh leaf is macerated } \\
\text { in water. }\end{array}$ & $\begin{array}{l}\text { A small quantity, } \\
\text { twice daily for three } \\
\text { days. }\end{array}$ \\
\hline 4 & Sterculia setigera & Kukkuki & $\begin{array}{l}\text { Stem- } \\
\text { Bark }\end{array}$ & 8 & $\begin{array}{l}\text { Dried powdered bark is } \\
\text { soaked in a hot water } \\
\text { and allow to stand for } \\
10 \mathrm{~min} \text {. }\end{array}$ & $\begin{array}{l}\text { Taken twice daily } \\
\text { until relieved. }\end{array}$ \\
\hline 5 & Bauhinia rufescens & $\begin{array}{l}\text { Matsatsagi or } \\
\text { Jirga }\end{array}$ & Seed & 8 & $\begin{array}{l}\text { Soak the powdered } \\
\text { seed in milk for } 5 \\
\text { minutes. }\end{array}$ & $\begin{array}{l}\text { Half a small cup, } \\
\text { three times daily for } \\
\text { three days. }\end{array}$ \\
\hline 6 & Parkia biglobosa & Dorawa & $\begin{array}{l}\text { Stem- } \\
\text { Bark / } \\
\text { Root }\end{array}$ & 9 & $\begin{array}{l}\text { Boil the stem-bark or } \\
\text { the root with potash } \\
\text { and allowed to cool. }\end{array}$ & $\begin{array}{l}\text { Two cups daily until } \\
\text { relieved. }\end{array}$ \\
\hline 7 & $\begin{array}{l}\text { Securidaca } \\
\text { longepedunculata }\end{array}$ & $\begin{array}{l}\text { Uwar } \\
\text { magunguna }\end{array}$ & $\begin{array}{l}\text { Stem- } \\
\text { Bark / } \\
\text { Leaf }\end{array}$ & 4 & $\begin{array}{l}\text { Soak the dried } \\
\text { powdered part in } \\
\text { diluted milk }\end{array}$ & $\begin{array}{l}\text { Taken twice a day. } \\
\text { Warm it before } \\
\text { drinking. }\end{array}$ \\
\hline 8 & $\begin{array}{l}\text { Catunaregam } \\
\text { nilotica }\end{array}$ & $\begin{array}{l}\text { Barbaji, } \\
\text { Tsibra, } \\
\text { Chibra }\end{array}$ & $\begin{array}{l}\text { Stem- } \\
\text { Bark / } \\
\text { root }\end{array}$ & 5 & $\begin{array}{l}\text { Use either dry or fresh } \\
\text { stem-bark / root. Boil } \\
\text { in water. }\end{array}$ & $\begin{array}{l}\text { Half a cup three } \\
\text { times daily until } \\
\text { relieved. }\end{array}$ \\
\hline 9 & Ziziphus abyssinica & Magarya & Leaf & 4 & $\begin{array}{l}\text { One spoon of the dried } \\
\text { powdered leaf is mixed } \\
\text { with diluted milk. }\end{array}$ & $\begin{array}{l}\text { A small cup twice } \\
\text { daily }\end{array}$ \\
\hline 10 & Tamarindus indica & Tsamiya & Leaf & 5 & $\begin{array}{l}\text { Boil the fresh leaf with } \\
\text { red potash and cool. }\end{array}$ & $\begin{array}{l}\text { A cup twice daily for } \\
\text { seven days. }\end{array}$ \\
\hline 11 & Mangifera indica & Mangwaro & $\begin{array}{l}\text { Stem- } \\
\text { Bark }\end{array}$ & 3 & $\begin{array}{l}\text { Dried powdered bark is } \\
\text { soaked in water mixed } \\
\text { with honey. }\end{array}$ & $\begin{array}{l}\text { Half a cup three } \\
\text { times daily for ten } \\
\text { days. }\end{array}$ \\
\hline
\end{tabular}

Table-2: Antisnake Venom Activity of Methanol Root Extract of Calotropis procera

\begin{tabular}{|c|c|c|c|c|c|c|c|}
\hline Group & Treatment & $\begin{array}{c}\text { Extract } \\
\mathbf{( m g / k g} \\
\mathbf{b} \mathbf{w t})\end{array}$ & $\begin{array}{c}\text { Venom } \\
(\mathbf{m g} / \mathbf{k g} \\
\mathbf{b} \mathbf{w t .})\end{array}$ & $\begin{array}{c}\text { Standard } \\
\text { Antivenin } \\
(\mathbf{1 m l} / \mathbf{0 . 6 m g} \\
\mathbf{v e n o m})\end{array}$ & $\frac{\text { Survival }}{\text { Total }}$ & $\begin{array}{c}\text { \% } \\
\text { Survival }\end{array}$ & $\begin{array}{c}\text { Mean } \\
\text { Survival } \\
\text { Time (h) }\end{array}$ \\
\hline 1 & Control & - & - & - & $5 / 5$ & 100 & $24.00 \pm 00^{\mathrm{c}}$ \\
\hline 2 & Venom Only & - & 0.8 & - & $0 / 5$ & 0 & $0.88 \pm 0.11^{\mathrm{a}}$ \\
\hline 3 & Venom + Extract & 200 & 0.8 & - & $0 / 5$ & 0 & $11.25 \pm 1.54^{\mathrm{b}}$ \\
\hline 4 & Venom + Extract & 400 & 0.8 & - & $0 / 5$ & 0 & $18.52 \pm 1.50^{\mathrm{bc}}$ \\
\hline 5 & Extract Only & 400 & - & - & $5 / 5$ & 100 & $24.00 \pm 0.00^{\mathrm{c}}$ \\
\hline 6 & $\begin{array}{c}\text { Venom + } \\
\text { Antivenin }\end{array}$ & - & 0.8 & 1.3 & $5 / 5$ & 100 & $24.00 \pm 0.00^{\mathrm{c}}$ \\
\hline
\end{tabular}

Mean survival times are presented as Mean \pm SEM $(n=5)$.

Mean Survival Times carrying different superscripts from the venom control (group 2) are significantly $(\mathrm{P}<0.05)$ different using ANOVA and Duncan multiple range test. 
Table-3: Antisnake Venom Activity of Methanol Stem-Bark Extract of Parkia biglobosa

\begin{tabular}{|c|c|c|c|c|c|c|c|}
\hline Group & Treatment & $\begin{array}{l}\text { Extract } \\
\text { (mg/kg } \\
\text { b. wt.) }\end{array}$ & $\begin{array}{l}\text { Venom } \\
\text { (mg/kg } \\
\text { b. wt.) }\end{array}$ & $\begin{array}{c}\text { Standard } \\
\text { Antivenin } \\
(1 \mathrm{ml} / \mathbf{0 . 6 m g} \\
\text { venom) } \\
\end{array}$ & $\frac{\text { Survival }}{\text { Total }}$ & $\begin{array}{c}\% \\
\text { Survival }\end{array}$ & $\begin{array}{c}\text { Mean } \\
\text { Survival } \\
\text { Time (h) }\end{array}$ \\
\hline 1 & Control & - & & $\ldots$ & $5 / 5$ & 100 & $24.00 \pm 0.00^{\mathrm{c}}$ \\
\hline 2 & Venom Only & & 0.8 & $=$ & $0 / 5$ & 0 & $0.95 \pm 0.27^{\mathrm{a}}$ \\
\hline 3 & Venom + Extract & 200 & 0.8 & - & $0 / 5$ & 0 & $12.29 \pm 4.55^{\mathrm{b}}$ \\
\hline 4 & Venom + Extract & 400 & 0.8 & $=$ & $0 / 5$ & 0 & $14.04 \pm 4.79^{\mathrm{b}}$ \\
\hline 5 & Extract Only & 400 & & & $5 / 5$ & 100 & $24.00 \pm 0.00^{\mathrm{c}}$ \\
\hline 6 & Venom + Antivenin & _- & 0.8 & 1.3 & $4 / 5$ & 80 & $23.54 \pm 0.74^{\mathrm{c}}$ \\
\hline
\end{tabular}

Mean survival times are presented as Mean $\pm \operatorname{SEM}(n=5)$.

Mean Survival Times carrying different superscripts from the venom control (group 2 ) are significantly $(\mathrm{P}<0.05)$ different using ANOVA and Duncan multiple range test.

Table-4: Antisnake Venom Activity of Methanol Seed Extract of Bauhinia rufescens

\begin{tabular}{|c|c|c|c|c|c|c|c|}
\hline Group & Treatment & $\begin{array}{c}\text { Extract } \\
\text { (mg/kg } \\
\text { b. wt.) }\end{array}$ & $\begin{array}{l}\text { Venom } \\
\text { (mg/kg } \\
\text { b. wt.) }\end{array}$ & $\begin{array}{c}\text { Standard } \\
\text { Antivenin } \\
\text { (1ml/0.6mg } \\
\text { venom) }\end{array}$ & $\frac{\text { Survival }}{\text { Total }}$ & $\begin{array}{c}\% \\
\text { Survival }\end{array}$ & $\begin{array}{l}\text { Mean Survival } \\
\text { Time (h) }\end{array}$ \\
\hline 1 & Control & & & & $5 / 5$ & 100 & $24.00 \pm 0.00^{\mathrm{c}}$ \\
\hline 2 & Venom Only & & 0.8 & $\ldots$ & $0 / 5$ & 0 & $0.89 \pm 0.23^{\mathrm{a}}$ \\
\hline 3 & Venom + Extract & 200 & 0.8 & _ & $0 / 5$ & 0 & $8.19 \pm 5.33^{b}$ \\
\hline 4 & Venom + Extract & 400 & 0.8 & _ & $1 / 5$ & 20 & $18.66 \pm 4.32^{\mathrm{bc}}$ \\
\hline 5 & Extract Only & 400 & & & $5 / 5$ & 100 & $24.00 \pm 0.00^{c}$ \\
\hline 6 & $\begin{array}{c}\text { Venom + } \\
\text { Antivenin }\end{array}$ & - & 0.8 & 1.3 & $5 / 5$ & 100 & $24.00 \pm 0.00^{\mathrm{c}}$ \\
\hline
\end{tabular}

Mean Survival Times carrying different superscripts from the venom control (group 2 ) are significantly $(\mathrm{P}<0.05)$ different using ANOVA and Duncan multiple range test.

Table-5: Antisnake Venom Activity of Methanol Stem-Bark Extract of Sterculia setigera

\begin{tabular}{|c|c|c|c|c|c|c|c|}
\hline Group & Treatment & $\begin{array}{c}\text { Extract } \\
(\mathbf{m g} / \mathbf{k g} \\
\mathbf{b .} \mathbf{w t} .)\end{array}$ & $\begin{array}{c}\text { Venom } \\
(\mathbf{m g} / \mathbf{k g} \\
\mathbf{b .} \mathbf{w t .})\end{array}$ & $\begin{array}{c}\text { Standard } \\
\text { Antivenin } \\
(\mathbf{1 m l} / \mathbf{0 . 6 m g} \\
\text { venom) }\end{array}$ & $\begin{array}{c}\frac{\text { Survival }}{\text { Total }} \\
\text { Survival }\end{array}$ & $\begin{array}{c}\text { Mean } \\
\text { Survival Time } \\
(\mathbf{h})\end{array}$ \\
\hline 1 & Control & - & - & - & $5 / 5$ & 100 & $24.00 \pm 0.00^{\mathrm{c}}$ \\
\hline 2 & Venom Only & - & 0.8 & - & $0 / 5$ & 0 & $0.93 \pm 0.19^{\mathrm{a}}$ \\
\hline 3 & Venom + Extract & 200 & 0.8 & - & $0 / 5$ & 0 & $3.98 \pm 0.52^{\mathrm{a}}$ \\
\hline 4 & Venom + Extract & 400 & 0.8 & - & $0 / 5$ & 0 & $5.96 \pm 2.79^{\mathrm{b}}$ \\
\hline 5 & Extract Only & 400 & - & - & $5 / 5$ & 100 & $24.00 \pm 0.00^{\mathrm{c}}$ \\
\hline 6 & Venom + Antivenin & - & 0.8 & 1.3 & $5 / 5$ & 100 & $24.00 \pm 0.00^{\mathrm{c}}$ \\
\hline
\end{tabular}

Mean survival times are presented as Mean \pm SEM $(n=5)$.

Mean Survival Times carrying different superscripts from the venom control (group 2 ) are significantly $(\mathrm{P}<0.05)$ different using ANOVA and Duncan multiple range test.

Table-6: Comparative Analysis of Mean Survival Times of the Animals Treated with Selected Plants

\begin{tabular}{|c|c|c|c|c|c|c|}
\hline Group & Treatment & \multirow{2}{*}{$\begin{array}{c}\text { Extract } \\
(\mathbf{m g} / \mathbf{k g} \\
\end{array}$} & & \multicolumn{5}{|c|}{ Mean Survival Time (h) } \\
\cline { 4 - 7 } & & b. wt.) & $\begin{array}{c}\text { C. procera } \\
\text { Root }\end{array}$ & $\begin{array}{c}\text { P. biglobosa Stem- } \\
\text { Bark }\end{array}$ & $\begin{array}{c}\text { B. rufescens } \\
\text { Seed }\end{array}$ & $\begin{array}{c}\text { S. setigera Stem- } \\
\text { Bark }\end{array}$ \\
\hline 1 & Control & - & $24.00 \pm 0.00^{\mathrm{a}}$ & $24.00 \pm 0.00^{\mathrm{a}}$ & $24.00 \pm 0.00^{\mathrm{a}}$ & $24.00 \pm 0.00^{\mathrm{a}}$ \\
\hline 2 & Venom Only & - & $0.88 \pm 0.11^{\mathrm{a}}$ & $0.95 \pm 0.27^{\mathrm{a}}$ & $0.89 \pm 0.23^{\mathrm{a}}$ & $0.93 \pm 0.19^{\mathrm{a}}$ \\
\hline 3 & Venom + Extract & 200 & $11.25 \pm 1.54^{\mathrm{b}}$ & $12.29 \pm 4.55^{\mathrm{b}}$ & $8.19 \pm 5.33^{\mathrm{b}}$ & $3.98 \pm 0.54^{\mathrm{a}}$ \\
\hline 4 & Venom + Extract & 400 & $18.52 \pm 1.50^{\mathrm{bc}}$ & $14.04 \pm 4.79^{\mathrm{b}}$ & $18.66 \pm 4.32^{\mathrm{bc}}$ & $5.96 \pm 2.79^{\mathrm{a}}$ \\
\hline 5 & Extract Only & 400 & $24.00 \pm 0.00^{\mathrm{a}}$ & $24.00 \pm 0.00^{\mathrm{a}}$ & $24.00 \pm 0.00^{\mathrm{a}}$ & $24.00 \pm 0.00^{\mathrm{a}}$ \\
\hline 6 & Venom + Antivenin & - & $24.00 \pm 0.00^{\mathrm{a}}$ & $23.54 \pm 0.74^{\mathrm{a}}$ & $24.00 \pm 0.00^{\mathrm{a}}$ & $24.00 \pm 0.00^{\mathrm{a}}$ \\
\hline
\end{tabular}

Values are presented as Mean \pm SEM $(\mathrm{n}=5)$.

Mean Survival Times carrying different superscripts (along the row) are significantly $(\mathrm{P}<0.05)$ different using ANOVA and Duncan multiple range test.

\section{DISCUSSION}

The plant kingdom provides an inexhaustible source of various herbal compounds with pharmacological potential $[11,12]$. A plethora of medicinal plants, available locally are used widely by traditional healers in the form of plant sap, pastes, decoctions, powders and pills in the treatment of snakebite envenomation [13]. 
Herbal antivenoms have been reported to neutralize toxic venom constituents through several mechanisms. These include; inhibition of venom enzymes, inactivation of venom toxic proteins, antioxidant activity, adjuvant action, chelation activity and combination of these activities [14].

Various phytochemicals with protein binding properties, active against snake envenomation include flavonoids, polyphenols, saponins, tannins, terpenoids, xanthenes, quinonoids, steroids and alkaloids. These bind to toxic venom proteins thereby inactivating them [15]. They could also competitively block the target receptors.

Among the selected plant materials in this research, B. rufescens seed extract was identified as the most effective against the mixed venoms of Naja nigricollis, Echis ocellatus and Bitis arietans as increased mean survival time (MST) was recorded for each of the administered doses (Table 4). Thus, the MSTs of the treatment groups were significantly increased, and the group that received the highest dose of the plant extract $(400 \mathrm{mg} / \mathrm{kg} \mathrm{b}$. wt.) had higher animals survival rate than those that received lower dose of $200 \mathrm{mg} / \mathrm{kg} \mathrm{b}$. wt., which may be due to a number of factors such as dose of administration as reported by Abubakar et al., [16] and Sani et al., [17] who observed increase in survival time with administered plant extract in a dose-dependent manner.

The antivenom activities observed in the rats administered with the plants extracts may be attributed to the possible presence of any of phenols, steroids, glycosides, tannins, saponins or terpenoids in the plant extracts [18]. The phytochemical components of these plants materials have been established in previous studies and these studies have linked presence of the bioactive compounds to antisnake venom activities [14, 19].

The antisnake venom activities of the plants extracts in neutralizing the snake venom effects may also be attributed to the presence of phenols; as plant phenols from the aqueous extracts of Pentace burmanica, Pithecellebium dulce, Areca catechu and Quercus infectoria have been shown to block nonselectively the nicotinic acetylcholine receptor by precipitation of Naja kaouthia venom [20, 21]. Phenols have also been shown to possess dose-dependent inhibitory effects on phospholipase $\mathrm{A}_{2}$, hyaluronidase, and L-amino acid oxidase of Calloselasma rhodostoma and Naja naja kaouthia venoms in in vitro tests [22].

Tannins from persimmon, a fruit from Diospyrus kaki inhibits oedema in mice induced by sea snake and also improved the survival time in mice injected with Laticauda semifasciata and Trimeresurus flavoviridis venom [23]. Therefore, prolonged mean survival time observed in the treated groups for each plant extract may be attributable to the presence of tannins in the methanol extracts.

Terpenoids, flavonoids and polyphenols possess protein binding and enzyme inhibiting properties and also inhibit snake venom phospholipase $A_{2}$ activities of both viper and cobra venom [14, 24]. A natural triterpenoid saponin extracted from the root of Glycyrrhiza glabra (licorice), has been characterized as a thrombin inhibitor [25]. This compound is known for its anti-inflammatory activity and it also exhibits antithrombotic properties against snake venom in vivo [26]. The possible presence of terpenoids, flavonoids and saponins in the extracts may also have contributed to their antisnake venom activities.

\section{CONCLUSION}

The limitations of serum antivenin are well known and the world is searching for an alternative for snakebite treatment. Till date no suitable alternative measures are available, except the natural herbal remedies, which are showing promising expectations. The advantages of herbal compounds are that, they are cheap, easily available, and stable at room temperature and could neutralize a wide range of venom toxins. The methanol extracts of the selected medicinal plants showed antivenom activities against the mixed venoms of Naja nigricollis, Echis ocellatus and Bitis arietans with varying degrees of efficacy. B. rufescens seed extract was found to be the most potent. Its antivenom properties have been established. This research work has provided scientific proof on the antivenom properties of the selected medicinal plants. Hence, it lends support to the traditional use of the plants in the treatment of snakebites. Finally, these findings would be of importance in the area of drug development with a view to actualizing the substitution of conventional snakebite therapeutic options with effective, cheap, accessible and less allergic plant-based compounds.

\section{FUNDING}

This research work was fully sponsored by the Nigerian Tertiary Education Trust Fund (TETFund) through Institution-Based Research Grant with grant reference number; TETFUND/DESS/UNI/ALIERO/2018/RP/VOL.I,

Batch-14, RP-Disbursement, S/No: 03.

\section{REFERENCES}

1. Sani, I., Umar, A. A., Jiga, S. A., Bello, F., Abdulhamid, A., \& Fakai, I. M. (2020). Isolation Purification and Partial Characterization of Antisnake Venom Plant Peptide (BRS-P19) from Bauhinia rufescens (LAM FAM) Seed as Potential Alternative to Serum-Based Antivenin. Journal of Biotechnology Research, 6(4), 18-26.

2. Morais, V. (2018). Antivenom therapy: efficacy of premedication for the prevention of adverse reactions. J. Venom. Anim. Toxins Incl. Trop. Dis., 24:(7) $1-7$ 
3. Sani, I., Umar, R.A., Hassan, S.W., Faruq, U.Z., Abdulhamid, A., Bello, F. and Fakai, I.M. (2019). Major Enzymes from Snake Venoms: Mechanisms of Action and Pharmacological Applications. Asian J. Biol. Sci., 12(3): 396-403.

4. Dabai, T.J. (2010). Antisnake venom activity, Microbial and Phytochemical Screening of some Locally Used Medicinal Plants. M.Sc. Dissertation, Usmanu Danfodiyo University, Sokoto, Nigeria.

5. Aboubakar, O.B.F., Bella, N.M.T., Ngo lemba, T.E., Bilanda, D.C., \& Dimo, T. (2012). Antihypertensive Activity of Jateorhiza meacrantha (Menispermaceae) Aqueous Extract on Ethanol-induced Hypertension in Wister Albino Rats. Intern. J. Pharm. Sci., 4(2).

6. AUCC. (2009). Guide to the use and care of experimental animals. Animal use and Care Committee, National Veterinary Research Institute, Vom, Nigeria: vol. 1.

7. Goswami, P.K., Samant, M., \& Srivastava, R.S. (2014). Snake Venom, Anti-Snake Venom and Potential of Snake Venom. Inter. J. Pharm. Pharmec. Sci., 6(5): 4-7

8. Razi, M.T., Asad, M.H.H.B., Khan, T., Chaudhary, M.Z., Ansari, M.T., Arshad, M.A., \& Najamus Saqib, Q. (2011). Antihaemorrhagic (Antivenom) Potentials of Fagonia Cretica against Pakistani Cobra Venom (Naja Naja Karachiensis). Nat. Prod. Res., 25: 1902-1907

9. Dupont, S., Caffin, N., Bhandari, B., \& Dykes, G.A. (2006). In Vitro Antimicrobial Activity of Australian herb extracts against food related bacteria. Food Cont., 17: 929-932

10. Premendran, S.J., Salwe, K.J., Pathak, S., Brahmane, R. and Manimekalai, K. (2011). Anticobra venom activity of plant Andrographis paniculata and its comparison with polyvalent antisnake venom. J. Nat. Sci., Biol. Med., 2(2): 198-204.

11. Gupta, Y.K., \& Peshin S.S. (2012). Do herbal medicines have potential for managing snakebite envenomation? Toxicol. Int., 19:89-99.

12. Sani, I., Umar, R.A., Hassan, S.W., Faruq, U.Z., \& Bello, F. (2020). Isolation of Antisnake Venom Agents from Azadirachta indica (A. Juss) Leaf Extracts. Acad. J. Chem., 5(2): 10-16.

13. Faruq, U.Z., Zuru, A.A., Abdulrahman, F.W., \& Bilbis, L.S. (2002). Preliminary Screening of Sclerocarya birrea Bark as Snake Venom Antidote against Naja nigricollis. Nig. J. Biochem. Mol. Biol., Vol. 17:1

14. Sani, I., Umar, R.A., Hassan, S.W., \& Faruq, U.Z. (2018). Antisnake Venoms and their Mechanisms of Action: A Review. Saudi J. Med. Pharm. Sci., 4(5): 512-520

15. Sani, I., Umar, R.A., Hassan, S.W., Faruq, U.Z., Bello, F., \& Abdulhamid, A. (2019). Protective
Effect of Azadirachta indica Leaf Fractionated Extracts on Renal and Haematological Indices against Snake Venom Toxicity in Albino Rats. Res. J. Med. Plants, 13(3): 103-108.

16. Abubakar, M.S., Sule, M.I., Pateh, U.U., Abdurahman, E.M., Haruna, A.K., \& Jahun, B.M. (2000). In vitro snake venom detoxifying action of the leaf extract of Guiera senegalensis. J. Ethnopharmacol. 69(3): 253-257.

17. Sani I., A. Abdulhamid, F. Bello, A. Sulaiman and H. Aminu. (2020). Antisnake Venom Effect of Diospyros mespiliformis Stem-Bark Extract on Naja nigricollis Venom in Albino Rats. Singapore J. Sci. Res., 10(3): In Press.

18. Rajendran, K., Annie, S., Maneesh, M.R. and Vijaya, B. (2010). In vitro and In vivo anti snake venom (Daboia russelli) studies on various leaf extracts of Acalpha indica Linn. Int. J. Phytomed., 2: 217-220

19. Santhosh, M.S., Hemshekhar, M., Sunitha, K., Thushara, R.M., Jnaneshwari, S., Kemparaju, K., \& Girish, K.S. (2013). Snake Venom Induced Local Toxicities: Plant Secondary Metabolites as an Auxiliary Therapy. Mini-Rev. Med. Chem., 13: 106-123.

20. Leanpolchareanchai, J., Pithayanukul, P., \& Bavovada, R. (2009). Anti-necrosis potential of polyphenols against snake venoms. Immunopharm. Immunotoxicol., 31(4): 556-562.

21. Lewis, R.L., \& Gutmann, L. (2004). Snake venoms and the neuromuscular junction. Semin. Neurol. 24:175-179.

22. Akunyili, D.N., \& Akubue, P.I. (1986). Schumanniofoside, the antisnake venom principle from the stem bark of Schumanniophyton magnificum Harms, J. Ethnopharmacol., 18:176172.

23. Okonogi, T., Hattori, Z., Ogiso, A., \& Mitsui, S. (1979). Detoxification by persimmon tannin of snake venom and bacterial toxins. Toxicon, 17(5): $524-527$.

24. Alam, M.I., Auddy, B., \& Gomes, A. (1994). Isolation, purification and partial characterization of viper venom inhibiting factor from the root extract of the Indian medicinal plant sarsaparilla (Hemidesmus indicus R. Br.). Toxicon, 32(12): 1551-1557.

25. Francischetti, I.M., Monteiro, R.Q., Guimaraes, J.A., Francischetti, B. (1997). Identification of gycyrrhizin as a thrombin inhibitor. Biochem. Biophysiol. Comm. 235: 259.

26. Assafim, M., Ferreira, M.S, Frattani, F.S, Guimaraes, J.A., Monteiro, R.Q., \& Zingali, R.B. (2006). Counteracting effect of glycyrrhizin on the hemostatic abnormalities induced by Borthrops jararaca snake venom. J. Pharmacol., 148: 807. 